\title{
Farmers Perceptions about Climate Change, Management Practice and Their On-Farm Adoption Strategies at Rice Fields in Sapu and Kuntaur of the Gambia, West Africa
}

\author{
Fatou Bojang ${ }^{1 *}$, Seydou Traore ${ }^{2}$, Adama Togola ${ }^{1}$, Yacouba Diallo $^{1}$ \\ ${ }^{1}$ Institut Polytechnique Rural de Formation et de Recherches Appliquées, Katibougou, Mali \\ ${ }^{2}$ Centre Regional de Formation et d'Application en Agrométéorologie et Hydrologie Opérationnelle (AGRHYMET), Niger \\ Email: `fatoubojan22@gmail.com, straore789@gmail.com, adamatogola2001@yahoo.fr, yacdial2005@hotmail.com
}

How to cite this paper: Bojang, F., Traore, S., Togola, A. and Diallo, Y. (2020) Farmers Perceptions about Climate Change, Management Practice and Their On-Farm Adoption Strategies at Rice Fields in Sapu and Kuntaur of the Gambia, West Africa. American Journal of Climate Change, 9, 1-10.

https://doi.org/10.4236/ajcc.2020.91001

Received: August 27, 2019

Accepted: January 6, 2020

Published: January 9, 2020

Copyright $\odot 2020$ by author(s) and Scientific Research Publishing Inc. This work is licensed under the Creative Commons Attribution International License (CC BY 4.0).

http://creativecommons.org/licenses/by/4.0/

\begin{abstract}
Lowland rice production is highly vulnerable to extreme temperature as a result of climate change. The study analyses farmer's perception about climate change, management practice and their on-farm adoption strategies at the rice fields of Sapu and Kuntaur study location. The selected villages were the main rice production area, where rice is a monoculture crop. Focus group discussion was held with twenty rice growing farmers at Sapuand Kuntaur, and these were divided into five groups. Personal interview and key informant involves the two village head, two youth development chairpersons (VDC) and the extension worker overseeing both villages. This was done to gain in-depth knowledge on the subject matter. The analysis results indicated that more than $50 \%$ of the rice growing farmers were female and do not undergo formal education. More than $70 \%$ of them having perceived knowledge on the causes of climate change, inorganic fertilizer use, transplanting of rice seedlings, use of improved rice varieties, and on-farm coping strategies such as changing of cropping calendar and the use of pesticides to cope with current and future climate situation.
\end{abstract}

\section{Keywords}

Perception, Climate Change, Management Strategies, Adoption Strategies

\section{Introduction}

Climate change and increased climate variability are currently seen as major threats to agricultural production particularly on the side of rice farmers in Cen- 
tral River Region of the Gambia, coming on top of the long-lasting challenges of land degradation, poor drainage conditions in rice fields and inappropriate fertilizer applications. Rice production is part of the customs and traditions of the Central River Region South and North of the Gambia as it provides food, income and employment among small scale farmers [1].

The impacts of climate change will be felt more on Africa continent due to factors such as high level of climate variability, high dependence on natural resources, poor income status and poor infrastructural development to adjust to the devastating effects of climate change [2]. Most of the agricultural activity in Africa is rain fed which is highly climate dependant and the degree of the impacts would highly depend on the adaptive capacity of the small scale farmers.

Small scale farming in Africa will be greatly affected by climate change due to low adaptation strategy [3]. These impacts will vary from one region to the other [4]. Small scale farmers in West Africa have effectively utilized their scarce resources in order to cope with climate change and the problems now lie on sustainability, which means whether there will be continuous adoption of the same strategy in the future [5]. One of the pillars in response to climate change impacts is the adaptive capacity of small scale farmers, the rice farming sector will be greatly impacted by climate change without adaptation but the question is whether they will be able to continue to do this under a changing climate as lamented by Adger et al:; Rosenzweig and Parry [6] [7]. The farmers perceptions about climate change highly determine the kind of adaptation strategy to be adopted [8] [9]. Many researches on perception have supported inclusion of farmers' perception or indigenous knowledge into scientific knowledge [10] [11]. Little research was conducted on farmers perception on climate and how it impacts their adaptation options [12]. The knowledge of past and recent adaptation strategies would greatly help in the fight against climate change [13].

\section{Materials and Methods}

\subsection{Study Sites}

The field experiment was conducted in the Central River Region (CRR) on latitude 13.56 and longitude -15.93 . The study sites have unimodal rainfall distribution with the peak of the rain in August. Based on studies and local experiences have indicated that rain begins 15 days in the study area before the rest of the country receives rains. Rainfall varies from $900-700 \mathrm{~mm}$ and $600 \mathrm{~mm}$ to 500 $\mathrm{mm}$ respectively, the vegetation is mainly trees, shrubs and seasonal grasses. The main crops grown in the area are rice, vegetables, millet, groundnut, and maize. The region is purposefully selected because it is the food basket of the Gambia [1]. As shown in Figure 1, both study sites were located near the river Gambia, the river is the only source of irrigation.

The Gambia have a population of less than 1.7 million with about $80 \%$ of the inhabitants lived in urban areas [1], the rice farmer's population of Sapu and Kuntaur comprised of 89 according to the village head. 


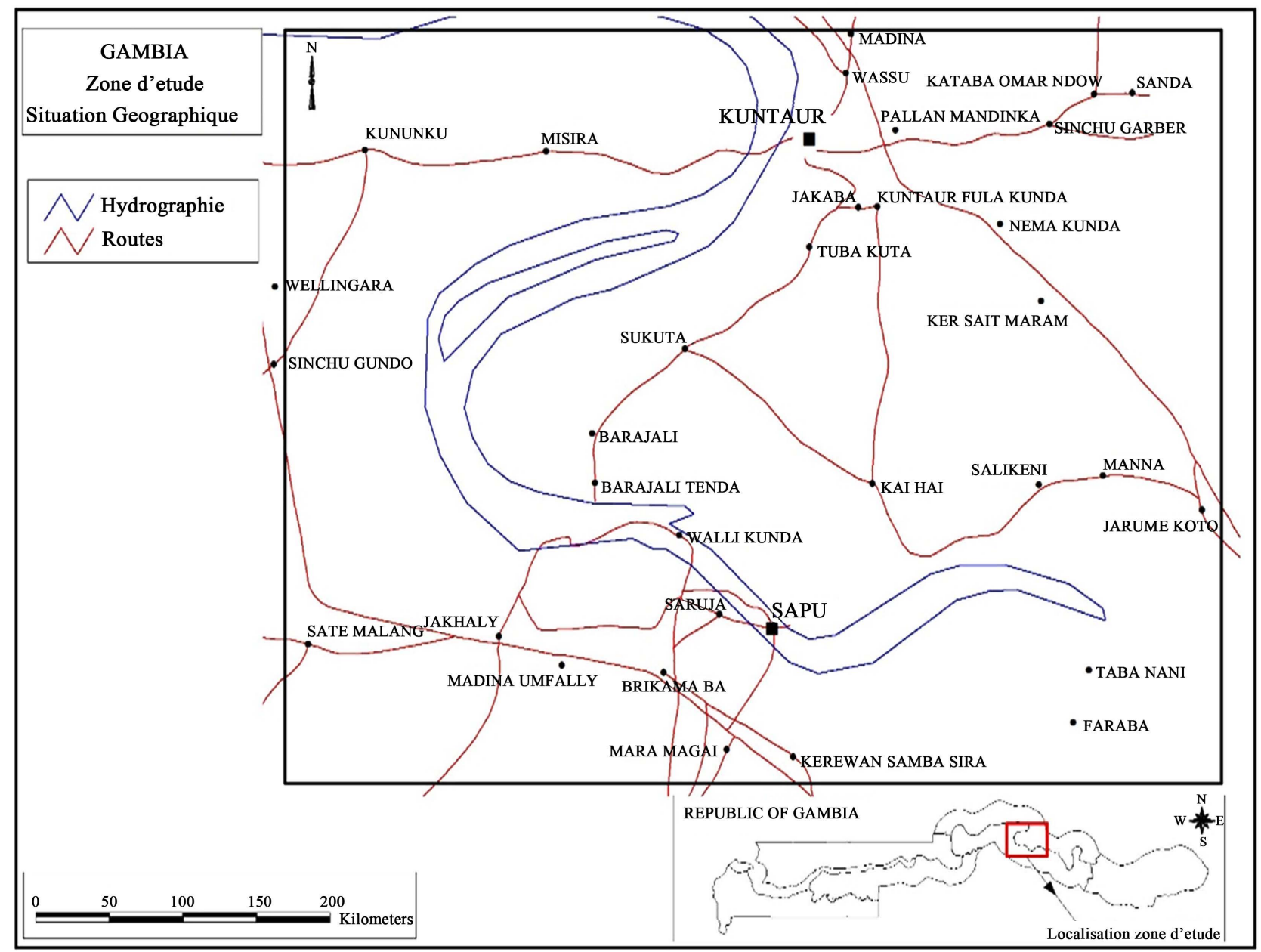

Figure 1. Map of Sapu and Kuntaur, the Gambia.

\subsection{Data Collection Methods}

A reconnaissance visit was made to the selected two villages of Sapu and Kuntaur for the validity of the study. A pretesting of fifteen rice farmers was carried out to ascertain the quality of the questionnaire. The validation of the questionnaire was done also with a focus group discussion held with farmers [14]. Key informant's interviews were conducted to facilitate optimum information regarding on rice production in the area and the targeted audience was the extension workers, farm leaders and village heads.

The respondents for the survey comprised of a population of 30 active rice farmers from each study site, comprising of 60 respondents from two study sites. Rice farmers from each study location were randomly selected using simple random sampling and this comprised of more than $50 \%$ of the sampled population. The selection process was also aided by village extension worker and the village head. A semi-structured questionnaire was administered on the theme: socio-demographic information, perception of climate change, perception onchemical fertilizer use, perception on varieties, transplanting dates and adaptation measure to boost their rice production. The questionnaires were read out to 
farmers in their own dialects for those who cannot read and write, whilst others directly filled the questionnaire, since they have been to school.

\subsection{Data Analysis}

Statistical packages of SPSS software version 20 (SPSS Inc., Chicago, IL, USA). Descriptive statistics such as percentages and sums were used to describe farmers' socio-demographic data, perceptions of climate change, selected rice varieties, chemical fertilizer application, transplanting of rice seedling and their on-farm adaptation measures to climate change.

\section{Results}

\subsection{Socio-Demographic Characteristic}

Majority of the respondents at Sapu and Kuntaur location were female (80\%), rice production in the Gambia were female dominated, men regards it as a female job and as a results only few males are involved in the cultivation activity [1]. This was in agreement with the focus group discussion and personal interview conducted with respondents. "Men are generally involved in groundnut and Maize cultivation whilst our wives engaged in rice production because rice production is less tedious than groundnut and maize", Most of the respondents (85\%) were married and (76\%) were Muslim, which is main religious group in the country. About (68\%) of the respondents did not have formal education due to the income status of the family could not afford to send their children to school, only few undergone primary and secondary education (see Table 1).

Table 1. Socio-demographic characteristics of respondents.

\begin{tabular}{ccc}
\hline & Frequency & Percentage (\%) \\
Sex & 48 & 80 \\
Female & 12 & 20 \\
Male & & \\
Civil status & 9 & 15 \\
Single & 51 & 85 \\
Married & & 76 \\
Religion & 46 & 23 \\
Islam & 14 & \\
Christian & & 68 \\
Education level & 41 & 20 \\
No education & 12 & 13 \\
Primary education & 8 & \\
Secondary education & & \\
\hline
\end{tabular}




\subsection{Farmers Perception of Climate Change Impacts}

As shown in Table 2, a majority of the respondents (77\%) have the perception that climate change would cause reduction of forest trees based on local experience, due to reduction in rains; many believed in the future there will be high losses of forest. Around (85\%) said climate change would increase temperature, which will have serious consequence on rice production, rice productivity is highly impacted by extreme temperature especially at flowering and heading. When respondents were asked about the opinion that climate change will increase rice yield, an estimation of few respondents agreed to the motion and majority of them knew that climate change will not increase rice yield, even though rice is a $\mathrm{C} 3$ crop and have the chance to benefit from $\mathrm{Co} 2$ fertilization under optimum temperature. $\mathrm{C} 3$ crops are the types of crops that undergo calvin cycle, that involves absorbing carbon dioxide from the atmosphere through the small opening of the leaves called stomata and convert it to sugars for its own use through the process called photosynthesis. From the personal interviews and focus group discussion held with rice farmers, they have said that rice crop is resistant to climate change as compared to maize and groundnut, because they were able to get good yields under climate situation. When the respondents were asked about the opinion that climate change will increase rice yield, around (35\%) disagreed to the opinion. About (50\%) of the surveyed participants disagree to the motion that pest and disease would favour climate change, they already have the perceived knowledge that pest and disease aggravate during hot weather. The main source of irrigation at both study location is river and many of them (56\%) said their water supply would be affected if the trend in the climate continues without adaptation in place.

\subsection{Farmers Perception on Inorganic Fertilizer Use}

The study, as it was shown in Table 3, states that most of the farmers (96\%) have agreed to the concept that inorganic fertilizer increased grain yields. But due to their income status many of them cannot afford buying inorganic fertilizer and they rely on compost and farm yard manure. Regardless of their inability to have easy access to inorganic fertilizer, many still beliefs that there cannot be any

Table 2. Rice farmers perception on impacts of climate change.

\begin{tabular}{ccccccc}
\hline & Agree & $\%$ & Disagree & $\%$ & $\begin{array}{c}\text { Not } \\
\text { sure }\end{array}$ & $\%$ \\
\hline Climate change would reduce forest trees & 50 & 77 & 6 & 10 & 8 & 13 \\
Climate change would increase temperature & 51 & 85 & 3 & 5 & 6 & 10 \\
$\quad \begin{array}{c}\text { Climate change will increase rice yield } \\
\quad\end{array}$ & 21 & 25 & 29 & 35 & 10 & 40 \\
$\begin{array}{c}\text { Pest and diseases would be } \\
\text { favoured by climate change }\end{array}$ & 18 & 20 & 15 & 50 & 27 & 30 \\
$\begin{array}{c}\text { Water supply from the river would } \\
\text { be reduced by climate change }\end{array}$ & 34 & 56 & 20 & 33 & 6 & 11 \\
\hline
\end{tabular}


Table 3. Rice farmers perception of inorganic fertilizer use.

\begin{tabular}{ccccccc}
\hline & Agree & $\%$ & Disagree & $\%$ & $\begin{array}{c}\text { Not } \\
\text { sure }\end{array}$ & $\%$ \\
\hline $\begin{array}{c}\text { More inorganic fertilizer more yields } \\
\quad 54\end{array}$ & 96 & 6 & 4 & 0 & 0 \\
$\begin{array}{c}\text { Inorganic fertilizers increased } \\
\text { pest and disease infestation on yield }\end{array}$ & 21 & 35 & 15 & 25 & 24 & 40 \\
$\begin{array}{c}\text { Inorganic fertilizer is better and } \\
\text { cheaper than organic fertilizer }\end{array}$ & 20 & 33 & 35 & 58 & 5 & 8 \\
\hline
\end{tabular}

effective rice production without applying inorganic fertilizer, according to focus group discussion and personal interviews held with them. Regarding the type of fertilizer many prefers NPK whilst other prefer urea as a choice of fertilizer. The opinion as whether inorganic fertilizer increased pest and disease occurrence, (35\%) agreed, (25\%) did not agree and (40\%) were not sure of the opinion. Many of them (58\%) disagreed to the motion that inorganic fertilizers are cheaper and better than organic fertilizer, they have the perception that the long term usage of inorganic fertilizer can destroy their soil. Most of them used it and they claimed that inorganic fertilizer gives quick response to rice crop.

\subsection{Perception on Transplanting}

Most of the respondents ( $80 \%$ ) have the belief that transplanting rice seedlings would give high yield as indicated in Table 4 and due to that effect nurseries are conducted which are later transplanted into the field. Majority of the farmers (58\%) have the perception that transplanting rice seedling at closer distance would not to give high yields based on the interview conducted with them and if they are asked why no reason is given but based on their own instinct. About (71\%) of the respondents also mentioned that transplanting tall seedling would not give high yield and most of them transplant very young seedlings (around 10 days old) to their field and when asked why, many said the idea was introduced by extension workers and it yielded good results, that is why they adopt the innovation. Finally, about (66\%) agreed that transplanting during hot weather increases the attack of pest and diseases and that it is not advisable to transplant during that condition. All this answers were close to the current scientific findings [1].

\subsection{Perceptions on Varieties Selection}

Based on the local experiences of the respondents on rice varieties as mentioned in Table 5, many (58\%) said improved rice varieties yield more than the traditional variety, thereby disagreeing the motion that traditional varieties yielded more than improved varieties. About (35\%) of the respondents also agreed that traditional varieties yield more than improved varieties. About (23\%) of the respondents were of the opinion that traditional varieties can tolerated extreme environments than the improved variety, whilst (46\%) of them did not agree that traditional variety withstand harsh environments that the improved rice variety 
Table 4. Rice farmers perception of transplanting rice seedlings.

\begin{tabular}{ccccccc}
\hline & Agree & $\%$ & Disagree & $\begin{array}{c}\text { Not } \\
\text { sure }\end{array}$ & $\%$ \\
\hline Transplanting of rice gives high yields & 48 & 80 & 9 & 15 & 3 & 5 \\
Transplanting at shorter distance gives high yields & 10 & 16 & 35 & 58 & 15 & 26 \\
$\begin{array}{c}\text { Transplanting of tall seedlings gives high yields } \\
\text { Transplanting during hot months }\end{array}$ & 7 & 11 & 43 & 71 & 10 & 18 \\
$\begin{array}{c}\text { increases pest and diseases damage. } \\
\text { The }\end{array}$ & 40 & 66 & 3 & 5 & 17 & 29 \\
\hline
\end{tabular}

Table 5. Rice farmers perception of varietal selection.

\begin{tabular}{ccccccc}
\hline & Agree & $\%$ & Disagree & $\%$ & $\begin{array}{c}\text { Not } \\
\text { sure }\end{array}$ & $\%$ \\
\hline $\begin{array}{c}\text { Traditional rice varieties yield } \\
\text { more than improved varieties }\end{array}$ & 21 & 35 & 35 & 58 & 4 & 7 \\
$\begin{array}{c}\text { Traditional varieties withstand unfavourable } \\
\text { conditions than improved varieties }\end{array}$ & 14 & 23 & 28 & 46 & 18 & 31 \\
$\begin{array}{c}\text { Traditional rice varieties are more } \\
\text { tastier than improved varieties }\end{array}$ & 17 & 28 & 31 & 51 & 12 & 21 \\
$\begin{array}{c}\text { Traditional varieties mature late } \\
\text { than improve varieties }\end{array}$ & 45 & 75 & 5 & 8 & 10 & 7 \\
$\begin{array}{c}\text { Traditional varieties are exposed to } \\
\text { lodging than the improved varieties }\end{array}$ & 49 & 81 & 5 & 8 & 6 & 11 \\
\hline
\end{tabular}

and $(31 \%)$ were not sure whether it is the traditional. Their reason was that traditional varieties were in existence for a long period and they exhibit characters to withstand unfavourable climate Most of the respondents (51\%) were not in agreement that traditional varieties are tastier than the improved rice variety. "due to nice tasty nature of the traditional rice variety, it is highly used as porridge in many homes and the most preferred during ceremonies", as quoted from focus group discussion. Almost (75\%) of the sampled rice farmers agreed that improved rice varieties are early maturing as compared to traditional varieties. About $(81 \%)$ of the respondents agree that traditional rice varieties are highly susceptible to lodging or falling down due to extreme events, due to their long height. Lodging is one of the problems farmers encounter in irrigated lowland rice production in the Gambia, most of grain yields are lost when lodging occurs in rice fields.

\subsection{Adoption Measures at the Farm Level}

About (85\%) of rice farmers have adopted changing their farming calendar as their main on-farm adaptation strategy. Based on their local experience, most of them know when to embark on cultivation, around (6\%) still maintain their usual time of cultivation whilst (9\%) of them were not sure if change of farming calendar could really help them boost their yields. Most of them (78\%) have 
stopped cultivating traditional varieties because it is late maturing and prefer to use improved varieties that are early maturing, about (16\%) of them still used their traditional varieties as an on-farm adoption measures, and do not want to switch to other rice varieties whilst $(6 \%)$ of the respondents were not sure in both opinions. Few of them (9\%) who can afford inorganic fertilizer, prefers using it as an adaptation measures to climate change, they still have the beliefs that inorganic fertilizer can greatly contribute to high yields regardless of weather condition, whilst (51\%) did not agreed the use inorganic fertilizer as an on-farm adoption strategy and (6\%) of them were not sure in both cases. Some of them (43\%) agreed using pesticides as an adoption measure to control pests and diseases on their rice fields, and many have the understanding that when rice fields are protected from pest and disease attack, grain yields would be improved, whilst about (40\%) did not agreed to the concept and (17\%) of them were not sure in both cases, see Table 6 .

\section{Discussion}

The management practices like the determination of optimum transplanting dates, selection of varieties and the application of inorganic fertilizers were the on-farm adoption strategies to combat climate change. Farmers already knew about extreme temperatures and variability in rainfall which is in agreement with meteorological records with exception of their perceived reduction of rainfall. This analysis results were in agreement with the findings of Cooper et al. [15]. Perception studies and scientific knowledge on climate change were also found in Apata et al:; Deressa et al. [16] [17]. Optimum planting dates plays a significant role in the attainment of maximum yield [9] [18], as a result, the findings of this study shows that majority of the respondents have changed their transplanting date to adjust to the current climate situation. Farmers already knew about the need for the application of fertilizers but their decision are largely influenced by the cost of fertilizer, their knowledge in fertilizer application and the availability of fertilizer [19]. Although rice fields at Sapu and Kuntaur study site did not face low water crises at the moment, since river is their main source of irrigation, but rice farmers do adjust their cropping calendar to avoid their production cycle been coinciding with extreme weather event such as floods and high temperature which is detrimental at critical stages of rice growth such as panicle initiation and grain filling stages.

Table 6. Rice farmers on-farm coping strategies.

\begin{tabular}{ccccccc}
\hline & Agree & $\%$ & Disagree & $\%$ & Not sure & $\%$ \\
\hline Changing of farming calendar & 51 & 85 & 4 & 6 & 5 & 9 \\
Use of improved rice varieties & 47 & 78 & 10 & 16 & 3 & 6 \\
Use of inorganic fertilizers & 5 & 9 & 51 & 85 & 4 & 6 \\
Use of pesticides & 26 & 43 & 24 & 40 & 10 & 17 \\
\hline
\end{tabular}




\section{Conclusion}

The findings of this research are in agreement with the findings of current scientific research, which say farmers are aware of climate change and they are using their own initiatives to overcome the impacts at the farm level. Farmers' productivity would be enhanced by the use of inorganic fertilizers, change of transplanting dates and varieties. Most of the farm adoption strategies included the change of crop calendar, use of inorganic fertilizer, use of improved rice varieties to adapt to climate variability. The education or training of farmers on weather or climate related area is crucial for effective adaptation strategy to enable decision making in agricultural production.

\section{Acknowledgements}

Special thanks to West African Science Service Centre for Climate Change and Adapted land use (WASCAL) for sponsoring the entire doctoral program. Similar appreciation goes to Prince Albert 2 Foundation for young researcher scholarship in collaboration with Intergovernmental Panel on Climate Change (IPCC) for financing my research work.

\section{Conflicts of Interest}

The authors of this article declare that there is not competing interest, there is no duplication of this article and all citations were duly acknowledged.

\section{References}

[1] Ceesay, M.M. (2004) Management of Rice Production Systems to Increase Productivity in the Gambia, West Africa. PhD Dissertation, Cornell University, Ithaca, 159 p.

[2] Tubiello, F.N., Amthor, J.S., Boote, K.J., Donatelli, M., Easterling, W., Fischer, G., Gifford, R.M., Howden, M., Reilly, J. and Rosenzweig, C. (2007) Crop Response to Elevated $\mathrm{CO}_{2}$ and World Food Supply: A Comment on "Food for Thought" by Long et al., Science, 312: 1918-1921, 2006. European Journal of Agronomy, 26, 215-223. https://doi.org/10.1016/j.eja.2006.10.002

[3] Sivakumar, M.V., Konaté, M. and Virmani, S.M. (1984) Agroclimatologie de l'Afrique de l'Ouest: Le Mali. Bulletin d'Information. Patancheru, ICRISAT.

[4] IPCC (2007) Summary for Policymakers. In: Solomon, S., Qin, D., Manning, M., Chen, Z., Marquis, M., Avert, K.B., Tigons, M. and Miller, H.L., Eds., Climate Change: The Physical Science Basis, Contribution of Working Group I to the Fourth Assessment Report of the Intergovernmental Panel on Climate Change, Cambridge University Press, Cambridge and New York, 996 p.

[5] Mortimore, M.J. and Adams, W.M. (2001) Farmer Adaptation, Change and "Crisis" in the Sahel. Global Environmental Change, 11, 49-57. https://doi.org/10.1016/S0959-3780(00)00044-3

[6] Adger, W.N., Huq, S., Brown, K., Conway, D. and Hulme, M. (2003) Adaptation to Climate Change in the Developing World. Progress in Development Studies, 3, 179-195. https://doi.org/10.1191/1464993403ps060oa

[7] Rosenzweig, C. and Parry, M.L. (1994) Potential Impact of Climate-Change on World Food Supply. Nature, 367, 133-138. https://doi.org/10.1038/367133a0 
[8] Roncoli, C., Ingram, K. and Kirshen, P. (2001) The Costs and Risks of Coping with Drought: Livelihood Impacts and Farmers Responses in Burkina Faso. Climate Research, 19, 119-132. https://doi.org/10.3354/cr019119

[9] Thomas, D.G., Twyman, C., Osbahr, H. and Hewitson, B. (2007) Adaptation to Climate Change and Variability: Farmer Responses to Intra-Seasonal Precipitation Trends in South Africa. Climatic Change, 83, 301-322. https://doi.org/10.1007/s10584-006-9205-4

[10] Mutiso, S.K. (1997) Indigenous Knowledge in Drought and Famine Forecasting in Machakos District, Kenya. In: Adams, W.M. and Slikkerveer, L.J., Eds., Indigenous Knowledge and Change in African Agriculture, Center for Indigenous Knowledge for Agriculture and Rural Development, Ames, 67-86.

[11] Sillitoe, P. (1998) The Development of Indigenous Knowledge: A New Applied Anthropology. Current Anthropology, 39, 223-252. https://doi.org/10.1086/204722

[12] Vedwan, N. (2006) Culture, Climate and the Environment: Local Knowledge and Perception of Climate Change among Apple Growers in Northwestern India. Journal of Ecological Anthropology, 10, 4-18. https://doi.org/10.5038/2162-4593.10.1.1

[13] Kitinya, K.T., Onwonga, R.N., Onyango, C., Mbuvi, J.P. and Kironchi, G. (2012) Climate Change and Variability: Farmers' Perception, Experience and Adaptation Strategies in Makueni County, Kenya. Asian Journal of Agriculture and Rural Development, 2, 411-421.

[14] Heong, K.L., Escalade, M.M., Sengsoulivong, V. and Schiller, J. (2002) Insect Management Beliefs and Practices of Rice Farmers in Laos. Agriculture, Ecosystems \& Environment, 92, 137-145. https://doi.org/10.1016/S0167-8809(01)00304-8

[15] Cooper, P.J.M., Dimes, J., Rao, K.P.C., Shapiro, B., Shiferaw, B. and Twomlow, S. (2008) Coping Better with Current Climatic Variability in the Rain-Fed Farming Systems of Sub-Saharan Africa: An Essential First Step in Adapting to Future Climate Change? Agriculture, Ecosystems and Environment, 126, 24-35. https://doi.org/10.1016/j.agee.2008.01.007

[16] Apata, T.G., Samuel, K. and Adeola, A. (2009) Analysis of Climate Change Perception and Adaptation among Arable Food Crop Farmers in South Western Nigeria. Contributed Paper Prepared for Presentation at the International Association of Agricultural Economists, Beijing, China, August 16.

[17] Deressa, T.T., Hassan, R.M., Ringler, C., Alemu, T. and Yesuf, M. (2009) Determinants of Farmers' Choice of Adaptation Methods to Climate Change in the Nile Basin of Ethiopia. Global Environmental Change, 19, 248-255. https://doi.org/10.1016/j.gloenvcha.2009.01.002

[18] IPCC (2007) Climate Change, Impacts, Adaptation, and Vulnerability, Contribution of Working Group II to the Fourth Assessment Report of the Intergovernmental Panel on Climate Change. Cambridge University Press, Cambridge, 976 p.

[19] Dobermann, A. (2012) IRRI Agronomy Challenge: How Much Fertilizers? http://irri.org/blogs/achim-dobermann-s-blog/irri-agronomy-challeng-how-much-f ertilizer 